distinctive, and can be confused with no other ware. Unfortunately, few jars have been found complete. As on a similar ware at Mohenjo-daro, the motifs are painted in a thick black paint on a highly burnished red slip, which is almost like lacquer. Among the motifs is a quadruped with an exaggerated plumelike tail, a peacock with a crest of bush or tree-like form, while another bird has a crest which terminates in two sun-motifs. The sun apparently is conceived as a rotating sphere with prominences, while the association of the sun with vegetation is indicated by plant or bud designs, which represent these solar prominences. The larger storage vessels are frequently decorated around the upper part only. Incised decoration of pottery is comparatively rare.

The pottery of the Jhukar people in fabric, mode of decoration and polychrome colouring is quite different from that of their predecessors. Violet-black paint was applied to a thick cream slip. Below the decorative border are bands of red paint. Nor have the shapes any relation to the earlier wares. A clue to origin is afforded by a herring-bone pattern painted alternately in red and black, which recalls the much earlier ornamentation on wares from Tell Halaf in Mesopotamia and that found by Sir Aurel Stein at Zayak in southern Baluchistan. One triple vessel of the Jhangar grey ware also recalls a find made by Sir Aurel Stein at Shahi-tump in Baluchistan. This suggests that these people too may have entered India from the west, and possibly at a much earlier date than has been thought.

The seals used by the Harappa people are like those found at Mohenjo-daro; but those of the Jhukar are more primitive, and for the most part made of pottery. In the Harappa period, Chandhu- daro was a great centre of bead making, and beads have been found in all stages from the raw material to the finished bead. Among them were the cornelian beads ornamented with designs in white, such as have been found in Sumer, but now known to have been manufactured in India or by Indians.

Metal working in copper and bronze was a craft that was largely practised. Heavy blade axes, a scoop, new to the ancient world, knives, daggers, razors in three shapes, and hairpins all show great experience in metal working.

A large number of toys of various kinds were found, and nearly every child must have had a toy cart, usually made in pottery and closely following the real cart in detail. Pottery rattles, owing to their substantial make, are rarely found broken. Of objects connected with religion, the most interesting are the figurines of the mother goddess, which are very different from the cult images of the goddess found at Mohenjo-daro. They were without legs, but had a hollow base to stand on. Like other figures of the Harappa culture, they were richly loaded with jewellery and their ears were pierced for ear-rings. Little jewellery was found.

Although the unique objects found on the site naturally have remained in India, the Archæological Survey has been generous in the allocation of objects to the Boston Fine Arts Museum. This is the only collection of objects illustrative of the early Indian civilization on exhibition outside India, and it is to be regretted that no similar collection is to be found in the museums of Great Britain. The exploration of the many sites of importance in India should not be left to other countries, and no British expedition organized to work in this most promising field.

\title{
Canadian Hydro-electric Power Development in 1936
}

\begin{abstract}
$\mathrm{A}^{\mathrm{L}}$ THOUGH the actual output of electricity in Canada during 1936 reached the new high level of $25,493 \frac{1}{2}$ million kilowatt-hours, the year was not specially remarkable for progress in development of the available water supplies. The annual review of hydro-electric power progress, issued by the Canadian Minister of Mines and Resources on January 1 of this year, shows that a comparatively small addition was made to the preceding year's aggregate of water-power developed in the Dominion, which at the end of 1935 had attained a figure of $7,909,115$ horse-power. New installations during the twelve months increased this by 36,475 to the new total of $7,945,590$. This is a little short of 8 millions, and, as the estimated total available is fully 40 millions, represents barely twenty per cent of the country's resources.

Notwithstanding the relatively small increment for the year, there is a number of projects actually under way which will add materially to the aggregate during the course of the next year or two. The progress of hydro-electric development in Canada within recent years has been largely influenced by the conditions arising out of a period of restricted output, lasting from 1930 until 1933 . Prior to 1930 , a number of important installations had been made in order to keep pace with a steadily growing demand for power
\end{abstract}

which, however, slackened and ceased about six years ago. It was not until May 1933 that the demand resumed an upward tendency which has continued. But it produced a corresponding relaxation of effort in regard to new enterprises, the effect of which has not yet quite dissipated itself, though there is every likelihood of its doing so in the very near future.

The new installations during 1936 consisted chiefly of additions to existing stations at High Falls (a fourth unit of 30,000 horse-power), on the Lievre River in the Province of Quebec, by the Maclaren-Quebec Power Co.; at Rat Rapids (a new unit of 1,750 horse-power), on the Albany River in the Province of Ontario ; and at Ruth Falls $(4,300$ horse-power) on East River Sheet Harbour, Nova Scotia. Several small installations have also been completed in British Columbia.

The Quebec Streams Commission has continued to maintain satisfactorily the desired regulation of flow on all the controlled rivers in the province by means of its extensive system of storage reservoirs, of which there are now seventeen, some of them of considerable size. It is actively pursuing investigations in regard to other available storage sites with the view of adapting them to the same purpose. BRysson CUNNINGHAM. 